In several patients the findings that metastases were forming in some organs but not others, despite infusion of viable tumour cells into the systemic circulation, provides direct evidence supporting the "seed and soil" hypothesis of Paget." This proposes that although haematogenously released tumour cells (seeds) "are carried in all directions they can only live and grow" if they lodge in an organ (soil) that is congenial. The clearest demonstration of this was in the patient (case 12) who was known before insertion of the shunt to have large haematogenous deposits in the liver and bone marrow but in whom there were no metastases or even tumour cells in the lungs or elsewhere at necropsy. With knowledge of such unusual patterns of spread and availability of tumour cells from the same patients it is possible to investigate the host factors responsible for local encouragement or suppression of metastatic growth; these are now being studied in this laboratory. A further point in relation to host related factors is that no cellular immune response was seen in response to micrometastases or isolated tumour cells. Also no features suggesting regression of tumour deposits-for example, dying tumour cells or host lymphoid infiltration-were seen even in those patients who survived for only short periods. It seems unlikely, therefore, that failure to form metastases is due to surveillance by the immune system.

In conclusion, our observations provide otherwise unobtainable information on mechanisms of metastasis in man and confirm that peritoneovenous shunting for malignant ascites does not carry the hazard of promoting clinically important metastasis.

This study was supported by the Cancer Research Campaign of
Great Britain, whose help we gratefully acknowledge. We also thank Mrs P Messer and Mrs B Carter for help in coordinating this study and in preparing the manuscript, and our clinical colleagues for referring cases for treatment.

\section{References}

Souter RG, Tarin D, Kettlewell MGW. Peritoneovenous shunts in the management of malignant ascites. $\mathrm{Br} \mathcal{F}$ Surg 1983;70:478-81.

2 Pollock AV. The treatment of resistant malignant ascites by insertion of a peritoneo-atrial Holter valve. Br f Surg 1975;62:104-7.

${ }^{3}$ Le Veen HH, Wapnick S, Grosberg S, Kinney MJ. Further experience with peritoneo-venous shunt for ascites. Ann Surg 1976;184:574-81.

4 Straus AK, Roseman DL, Shapiro TM. Peritoneovenous shunting in the management of malignant ascites. Arch Surg 1979;114:489-91.

5 Cheung DK, Raaf JH. Selection of patients with malignant ascites for a peritoneovenous shunt. Cancer 1982;50:1204-9.

${ }^{6}$ Reinhold RB, Lokich JJ, Tomashefski J, Costello P. Management of malignant ascites with peritoneovenous shunting. Am f Surg 1983;145: 455-7.

7 Qazi R, Savlov ED. Peritoneovenous shunt for palliation of malignant ascites. Cancer 1982;49:600-2.

${ }^{8}$ Maat B, Oosterlee J, Spaas JAJ, White H, Lammes FB. Dissemination of tumour cells via Le Veen shunt. Lancet 1979;i:988.

9 Smith RR, Sternberg SS, Paglia MA, Golbey RB. Fatal pulmonary tumor embolization following peritoneovenous shunting for malignant ascites. f Surg Oncol 1981;16:27-35.

10 Tarin D, Vass ACR, Kettlewell MGW, Price JE. Absence of metastatic sequelae during long-term treatment of malignant ascites by peritoneovenous shunting: a clinico-pathological report. Invasion and Metastasis $1984 ; 4: 1-12$.

11 Paget S. The distribution of secondary growths in cancer of the breast. Lancet $1889 ; \mathrm{i}: 571-3$.

(Accepted 22 December 1983)

\title{
Smoking and ulcerative colitis
}

\author{
RICHARD F A LOGAN, MARGARET EDMOND, KEVIN W SOMERVILLE, \\ MICHAEL I S LANGMAN
}

\begin{abstract}
In a case-control study of smoking and ulcerative colitis patients with the disease were much less likely to smoke than community controls matched for age and sex. The difference was substantial, with an estimated relative risk of 3.8 for non-smoking on current habits, was even larger (6.2) when habits at onset of the disease were examined, and was mainly accounted for by 42 of 55 patients who had given up smoking a mean of eight years before onset. The association could not be explained by confounding by social class.

These findings suggest that smoking directly or indirectly confers protection against ulcerative colitis.
\end{abstract}

\footnotetext{
University Departments of Therapeutics and Community Health, Queen's Medical Centre, Nottingham NG7 2UH

RICHARD F A LOGAN, MSC, MRCP, Wellcome research fellow in clinical epidemiology (now senior lecturer and honorary consultant physician) MARGARET EDMOND, BSC, research assistant

KEVIN W SOMERVILLE, MB, FRACP, lecturer in therapeutics

MICHAEL J S LANGMAN, MD, FRCP, professor of therapeutics

Correspondence to: Dr Richard F A Logan.
}

\section{Introduction}

The association of non-smoking and ulcerative colitis was first reported by Harries et al in 1982, who found that only $8 \%$ of patients with the disease were smokers compared with $44 \%$ of matched controls attending a fracture clinic. ${ }^{1}$ Jick and Walker, using data collected on hospital admissions, reported similar findings, as have other workers in preliminary reports of two smaller studies. ${ }^{2-4}$ It is not clear whether this unexpected association antedated the onset of disease or whether, as might seem likely, it followed the development or treatment of the disease. Furthermore, no study has included a community based control group, which is desirable when studying habits such as smoking which vary with health and social class.

We have carried out a case-control study inquiring into current and past smoking habits of patients with ulcerative colitis and community controls.

\section{Patients and methods}

The case series included all patients aged $16-80$ from a defined group of 52 general practices who were attending or had previously attended the City Hospital, Nottingham, for ulcerative colitis or proctitis. The hospital records of 124 patients were reviewed to confirm a diagnosis of ulcerative colitis and table I summarises the case details of the 124 patients approached. Ninety five of the patients 
(77\%) had attended the hospital in the past two years. In 64 cases $(52 \%)$ the diagnosis had been made during $1970-9$, and in $23(19 \%)$ the diagnosis had been made since then. The maximum extent of disease was determined by radiology in $93 \%$, which showed abnormalities in $64 \%$, and by colonoscopy in $5 \%$ of cases. In all cases where a rectal biopsy was available the findings were typical of ulcerative colitis; in a few patients the only rectal biopsies were performed elsewhere.

Each patient was matched with two controls, who were chosen by visiting the patient's general practitioner and using the practice records or age and sex register to select the next two people alphabetically of the same sex and aged within two years of the patient. When possible two more people were also selected to serve as reserves for those controls who subsequently were found to have moved house or died. Before approaching the controls the general practitioners were asked if there were medical or other reasons for not approaching any of them.

Each patient and the matched controls were sent similar letters and questionnaires. Older patients $(n=97)$ and their controls were sent a two page questionnaire, the first page asking some general questions about family size, occupation, marital state, and intake of tea, coffee, and alcohol, and the second page inquiring about past and present smoking habits. Twenty seven younger patients with recent onset of ulcerative colitis and their controls were sent a four page questionnaire which included an inquiry about aspects of their childhood and family background as well as the questions incorporated in the shorter questionnaire. If no reply was returned after six to eight weeks a second letter was sent with another copy of the original letter and questionnaire.

Analysis-To preserve the matched design of the study in the main

TABLE 1-Details of patients approached

\begin{tabular}{lccc}
\hline & Men & Women & Total \\
\hline No of patients & 58 & 66 & 124 \\
Mean age at diagnosis (years) [range] & $37 \cdot 1[13-75]$ & $34 \cdot 7[12-70]$ & $35 \cdot 9$ \\
Maximum determined extent of disease: & 12 & 23 & 35 \\
$\quad$ Rectum only & 6 & 9 & 15 \\
Sigmoid & 12 & 11 & 23 \\
Splenic flexure & 3 & 3 & 6 \\
Transverse colon & 22 & 19 & 41 \\
Pan-ulcerative colitis & 3 & 1 & 4 \\
Uncertain & 54 & 60 & 114 \\
Multiple attacks & 14 & 9 & 23 \\
No having colectomy & 53 & 61 & 114 \\
Rectal biopsy report in case record & $46 \cdot 2$ & $44 \cdot 9$ & $45 \cdot 5$ \\
Mean current age (years) & 56 & 64 & 120 \\
No of patients responding & & & \\
\hline
\end{tabular}

TABLE III-Aspects of smoking in patients and controls

\begin{tabular}{lcc}
\hline & Patients & Controls \\
\hline Current smoking habit (No of men only): & 10 & 44 \\
Cigarettes only $(\%)$ & 30 & 73 \\
Cigars $(\%)$ & 50 & 18 \\
Pipe $(\%)$ & 20 & 9 \\
Reported age at starting smoking (years): & $17 \cdot 0^{*}$ & $16 \cdot 0^{*}$ \\
Men & $17 \cdot 9$ & $18 \cdot 4$ \\
Women & $36 \cdot 1^{*}$ & $42 \cdot 2^{*}$ \\
Reported age at stopping smoking (years): & $34 \cdot 1$ & $33 \cdot 5$ \\
Men & & \\
Women & 22 & 22 \\
Reported maximum quantity of cigarettes smoked a day & 15 \\
$\quad$ Mer one year: & 15 & 18 \\
Women & 9 & 16 \\
Reported quantity of cigarettes currently smoked a day: & 15 \\
Men & & \\
Women & & \\
\hline
\end{tabular}

$* \mathrm{p}<0 \cdot 1$.

for matched analysis. In nine cases either the patient or both controls failed to reply.

Current smoking - Table II shows the percentage distribution of the various reported smoking habits, matching being ignored. There were 56 case-control sets where the patient reported being a nonsmoker at present and one or both controls reported being smokers, and 13 sets where the patient reported being a smoker and one or both controls were non-smokers. For men and women the relative risks for a non-smoker having ulcerative colitis were similar, for men being $4.0(95 \%$ confidence limits $1.7-9.2 ; \mathrm{p}<0.001)$ and for women $3.6(95 \%$ confidence limits $1.5-8 \cdot 7 ; \mathrm{p}<0.005)$. There was a tendency for patients to report being lifelong non-smokers (relative risks 1.6 and 1.4 for men and women respectively), but this was not significant.

Smoking at onset of disease-On the basis of the smoking habits three months before onset of the disease there were 57 case-control sets where the patient reported being a non-smoker and one or both controls were estimated to be smokers and eight sets where the patient reported being a smoker and one or both controls were non-smokers. For men the relative risk of developing ulcerative colitis for a nonsmoker three months before onset of the disease was $13.1(95 \%$ confidence limits $3 \cdot 6-47.0 ; p<0.001)$ and for women at the same time the relative risk was 3.6 (95\% confidence limits $1.5-8.9 ; \mathrm{p}<0.005)$.

Other aspects of smoking (table III)-The number of patients and controls who smoked or had smoked cigars or a pipe was only 20 $(14 \%)$, although recently there had been a tendency for smokers to change from cigarettes to small cigars or a pipe. When cigarette smoking alone was considered the relative risk estimates were not

TABLE II-Distribution of smoking habits in patients and controls

\begin{tabular}{|c|c|c|c|c|c|c|c|}
\hline \multirow[b]{2}{*}{ Smoking habit } & \multicolumn{2}{|c|}{$\%$ Men } & \multicolumn{2}{|c|}{$\%$ Women } & \multirow{2}{*}{$\begin{array}{l}\text { Combined relative risk } \\
\text { for non-smokers }\end{array}$} & \multirow[b]{2}{*}{$95 \%$ Confidence limits } & \multirow[b]{2}{*}{$x^{2}$} \\
\hline & $\begin{array}{l}\text { Patients } \\
(n=56)\end{array}$ & $\begin{array}{l}\text { Controls } \\
(n=88)\end{array}$ & $\begin{array}{l}\text { Patients } \\
(n=64)\end{array}$ & $\begin{array}{l}\text { Controls } \\
(n=113)\end{array}$ & & & \\
\hline $\begin{array}{l}\text { Never smoked } \\
\text { Ex-smokers } \\
\text { Current smokers } \\
\text { Smoking at disease onset } \\
\text { Smoking cigarettes at onset } \\
\text { Currently smoking cigarettes }\end{array}$ & $\begin{array}{r}25 \\
57 \\
18 \\
20 \\
15 \\
5\end{array}$ & $\begin{array}{l}20 \\
30 \\
50 \\
64 \\
59 \\
36\end{array}$ & $\begin{array}{l}59 \\
30 \\
11 \\
17\end{array}$ & $\begin{array}{l}51 \\
16 \\
33 \\
37\end{array}$ & $\begin{array}{l}1 \cdot 4 \\
3 \cdot 8^{*} \\
6 \cdot 2^{*} \\
6 \cdot 0^{*} \\
3 \cdot 1^{*}\end{array}$ & $\begin{array}{l}0 \cdot 8-2 \cdot 4 \\
2 \cdot 0-6 \cdot 9 \\
3 \cdot 0-12 \cdot 7 \\
2 \cdot 9-12 \cdot 3 \\
1 \cdot 7-5 \cdot 8\end{array}$ & $\begin{array}{r}1 \cdot 1 \\
20 \cdot 3 \\
32 \cdot 8 \\
30 \cdot 4 \\
14 \cdot 0\end{array}$ \\
\hline
\end{tabular}

${ }^{*} \mathrm{p}<0.001$.

analyses we used Miettinen's method for matched triplets, which necessitates dichotomous categorisation of risk factors. ${ }^{56}$ Other analyses used the unpaired Student's $t$ test. Smoking was arbitrarily defined as smoking more than five cigarettes a week, three cigars a week, or $14 \mathrm{~g}$ pipe tobacco a week for at least one year. For each patient and the matched controls the smoking habits just before the onset of ulcerative colitis were taken as the habit reported at age three months before onset of the disease in the patient.

\section{Results}

Of 124 patients identified initially, two were found subsequently to have left the area and two did not reply; hence the response rate was $97 \%$. Of the 248 controls approached, $201(81 \%)$ replied. Two patients and 45 controls replied after being sent the second letter. In 81 cases the patient and both controls replied and in 34 cases only one control replied, giving a total of 115 case-control sets available significantly different from those for all smoking habits either when cigar and pipe smokers were included as non-smokers or when they were left out of the analysis. Among current and ex-smokers the pattern of smoking was similar in women patients and their controls. In the men the patients who had smoked started a mean of one year older than the controls, and those who stopped did so six years earlier than the controls. Of 62 patients who smoked or had smoked, six thought that smoking might have had an effect on their ulcerative colitis and, of those, none reported a beneficial effect. Fifty six thought that smoking had had no effect, and six gave no answer.

Stopping smoking in relation to onset of disease-Of 55 patients ( $36 \mathrm{men}$ ) who had stopped smoking, 42 (30 men) had done so at least three months before the onset of symptoms (mean 8.5 years before). Four patients stopped within one year after onset of symptoms, nine stopped later, and one started smoking two years after onset of the disease.

Smoking and social class-Non-smoking among patients was independent of socioeconomic state as determined by the Registrar 
General's classification of social class, ${ }^{67}$ whereas the control population showed the expected increase in smoking with lower social class (table IV). Although patients and controls were not matched for social class, the social class distributions of the patient and control series were similar.

Smoking habit according to extent of disease and age at onset-The question whether smoking protected against a particular form of ulcerative colitis was studied by determining the relative risk according to extent of disease and age at onset (table V). The trend for less extensive colitis to be associated with non-smoking was not significant.

TABLE IV-Smoking at onset by social class distribution of patients and controls

\begin{tabular}{|c|c|c|c|c|c|c|}
\hline \multirow{2}{*}{ Social class } & \multicolumn{2}{|c|}{ Patients } & \multirow{2}{*}{$\%$ Smoking at onset } & \multicolumn{2}{|c|}{ Controls } & \multirow{2}{*}{$\%$ Smoking at onset } \\
\hline & No & $\%$ & & No & $\%$ & \\
\hline $\begin{array}{l}\text { I and II } \\
\text { III } \\
\text { IV and V } \\
\text { Not known }\end{array}$ & $\begin{array}{r}30 \\
68 \\
17 \\
3\end{array}$ & $\begin{array}{r}25 \\
58 \\
14 \\
3\end{array}$ & $\begin{array}{l}20 \\
16 \\
18 \\
33\end{array}$ & $\begin{array}{l}48 \\
94 \\
43 \\
16\end{array}$ & $\begin{array}{r}24 \\
47 \\
21 \\
8\end{array}$ & $\begin{array}{l}42 \\
54 \\
56 \\
31\end{array}$ \\
\hline Total & $118^{*}$ & & & 201 & & \\
\hline
\end{tabular}

*In two cases smoking habit at onset was uncertain.

TABLE V-Comparison of smoking habits at onset of disease for patients and controls subdivided by extent of disease and age at onset

\begin{tabular}{|c|c|c|c|c|c|}
\hline \multirow{2}{*}{$\begin{array}{l}\text { Category of } \\
\text { extent of } \\
\text { disease }\end{array}$} & \multirow{2}{*}{$\begin{array}{c}\text { No } \\
\text { of } \\
\text { cases* }\end{array}$} & \multicolumn{2}{|c|}{ Discordant sets } & \multirow{2}{*}{$\begin{array}{l}\text { Relative } \\
\text { risk }\end{array}$} & \multirow{2}{*}{$\begin{array}{l}95 \% \\
\text { Confidence } \\
\text { limits }\end{array}$} \\
\hline & & $\begin{array}{c}\text { Non-smoking } \\
\text { patient }\end{array}$ & $\begin{array}{c}\text { Smoking } \\
\text { patient }\end{array}$ & & \\
\hline $\begin{array}{l}\text { Proctosigmoid } \\
\text { Disease to splenic } \\
\text { flexure/transverse }\end{array}$ & 47 & 23 & 1 & $23 \cdot 0$ & $3 \cdot 6-147 \cdot 0$ \\
\hline Whole colon affected & $\begin{array}{l}26 \\
38\end{array}$ & $\begin{array}{l}11 \\
21\end{array}$ & $\begin{array}{l}1 \\
5\end{array}$ & $\begin{array}{l}9 \cdot 3 \\
3 \cdot 6\end{array}$ & $\begin{array}{l}1 \cdot 2-73 \cdot 0 \\
1 \cdot 4-9 \cdot 7\end{array}$ \\
\hline $\begin{array}{r}\text { Age at onset: } \\
<35 \text { years } \\
>35 \text { years }\end{array}$ & $\begin{array}{l}64 \\
51\end{array}$ & $\begin{array}{l}28 \\
29\end{array}$ & $\begin{array}{l}5 \\
3\end{array}$ & $\begin{array}{l}4 \cdot 8 \\
8 \cdot 8\end{array}$ & $\begin{array}{l}1 \cdot 9-12 \cdot 1 \\
2 \cdot 7-28 \cdot 0\end{array}$ \\
\hline
\end{tabular}

*No of cases where matched control data available.

\section{Discussion}

We have confirmed other reports that ulcerative colitis is strongly associated with non-smoking. Since the association has now been shown in five different studies with relative risk estimates of between 3 and 9, the possibility that this is a chance association appears negligible. ${ }^{1-4}$ A deficit of observed to expected deaths from lung cancer in a recent study of mortality in ulcerative colitis is also consistent with a real association. ${ }^{8}$

In the studies from Cardiff ${ }^{1}$ and Boston ${ }^{2}$ it seemed possible that the association might be secondary-that is, that the association could be explained by patients altering their smoking habits after developing the disease. Our results show that the association of non-smoking and ulcerative colitis existed at least three months before the onset of the clinical illness.

If the association is not due to chance and is not secondary, might some bias in reporting or in selecting cases and controls account for the findings? A systematic bias in reporting smoking habits resulting in patients with the disease underreporting not only current habits but also past habits, although plausible, seems unlikely, as both Harries et al and we have found that patients with Crohn's disease, approached in an identical manner, report smoking as much or more than a healthy control population. ${ }^{19}$

It is not clear how any bias in the selection of cases and controls might have operated. Except for selection by age the patients represented all those with ulcerative colitis from the general practices approached who attended the City Hospital, and since completing the study we have identified no other cases in these practices. Ideally the study should have concentrated on incident cases, but the disease is not common enough readily to allow such an approach. As, however, we took particular care to include both current and recent hospital attenders, and, as case fatality rates are low, a serious prevalence bias seems unlikely. The response rate of the patients was virtually complete, while that of the controls, though lower, was still reasonable. Non-responders are probably more likely to be smokers, so that any bias introduced is likely to act conservatively.

We do not therefore consider that our findings can be accounted for by any systematic bias, and we are left with the possibility that smoking is directly or indirectly protective against ulcerative colitis. As little is known of the aetiology of inflammatory bowel disease-whether ulcerative colitis or Crohn's disease-or of the effect of smoking on the colon, it is difficult to suggest a mechanism for a direct link, although the possibility cannot be excluded. ${ }^{10}$

Those who favour psychosomatic hypotheses might suggest that non-smokers are of a predisposed personality type. Although some evidence suggests that psychosomatic factors are concerned in ulcerative colitis, the findings are contradictory. ${ }^{11-14}$ It is worth noting that the association in our study was mostly accounted for by smokers who had given up the habit before developing the disease, which is some evidence against nonsmoking being linked by a personality type which predisposed independently to both ulcerative colitis and non-smoking.

It also seems unlikely that the association can be accounted for by some factor related to socioeconomic state. Although the controls were not formally matched according to the Registrar General's social class, the social class distribution of patient and control series was similar and the proportion of patients smoking was similar over all groups (table IV).

The number of pipe or cigar smokers among patients and controls was so small that it has not been possible to determine whether the protective association applies to all smoking or is specific for cigarettes. The study was also not large enough to determine whether a dose-response relation between amount smoked and relative risk of ulcerative colitis might exist. We conclude that the association between non-smoking and ulcerative colitis is real, that it reflects habits before the development of illness, and that non-smokers may directly or indirectly have an increased liability to the disease.

We acknowledge the generous support of RFAL as a Wellcome research fellow.

\section{References}

${ }^{1}$ Harries AD, Baird A, Rhodes J. Non-smoking: a feature of ulcerative colitis. Br Med f 1982;284:706.

2 Jick H, Walker AM. Cigarette smoking and ulcerative colitis. $N$ Engl $f$ Med 1983;308:261-3.

${ }^{3}$ Bures J, Fixa B, Komarkova O, Fingerland A. Non-smoking: a feature of ulcerative colitis. $\mathrm{Br}$ Med $\mathcal{F} 1982 ; 285: 440$.

${ }^{4}$ Gyde SN, Prior P, Taylor K, Allan RN. Cigarette smoking, blood pressure and ulcerative colitis. Gut 1983;24:A998.

${ }^{5}$ Miettinen OS. Estimation of relative risk from individually matched series. Biometrics $1970 ; 26: 75-86$.

6 Breslow NE, Day NE. Statistical methods in cancer research. Vol 1. The analysis of case-control studies. Lyon: IARC, 1980

7 Office of Population Censuses and Surveys. Registrar General's classification of occupations. London: HMSO, 1980.

${ }^{8}$ Gyde SN, Prior P, Dew MJ, Saunders V, Waterhouse JAH, Allan RN. Mortality in ulcerative colitis. Gastroenterology $1982 ; 83: 36-43$.

${ }^{9}$ Logan RFA, Somerville KW, Edmond M, Langman MJS. Is cigarette smoking associated with Crohn's disease? Gut 1983;24:A980.

${ }^{10}$ Kirsner JB, Shorter RG. Recent developments in "non-specific" inflammatory bowel disease. $N$ Engl f Med 1982;306:775-85, 837-48.

11 Engle GL. Studies of ulcerative colitis III. The nature of the psychological processes. Am $\mathcal{F}$ Med 1955;19:231-56.

12 Mendeloff AI, Monk M, Siegel CL, Lilienfeld A. Illness experience and life stresses in patients with irritable colon and with ulcerative colitis. $N$ Engl f Med 1970;282:14-7.

13 Monk M, Mendeloff AI, Siegel CL, Lilienfeld A. An epidemiological study of ulcerative colitis and regional enteritis among adults in Baltimore-III. 7 Chronic Dis 1970;22:565-78.

14 Helzer JE, Stillings WA, Chammas S, Norland CC, Alpens DH. A controlled study of the association between ulcerative colitis and psychiatric diagnoses. Dig Dis Sci 1982;27:513-8.

(Accepted 30 December 1983) 